\title{
Trace and rare earth elements determination in milk whey from the Veneto region, Italy
}

\author{
Raffaello Tedesco ${ }^{\text {a,b, }}$, Maria del Carmen Villoslada Hidalgo ${ }^{\text {a,b,c }}$, Massimiliano Vardè ${ }^{\text {b, d }}$, \\ Natalie M. Kehrwald ${ }^{\text {e }}$, Carlo Barbante ${ }^{\mathrm{a}, \mathrm{b}}$, Giulio Cozzi ${ }^{\mathrm{b}, \mathrm{a}}$ \\ a Department of Environmental Sciences, Informatics and Statistics (DAIS), Ca' Foscari University of Venice (UniVE), Via Torino 155, Venice-Mestre, 30172, Italy \\ ${ }^{\mathrm{b}}$ Institute of Polar Sciences, National Research Council of Italy, (CNR-ISP), Via Torino 155, Venice-Mestre, 30172, Italy \\ ${ }^{\mathrm{c}}$ CIC NanoGUNE BRTA, Tolosa Hiribidea 76, San Sebastian, 20018, Spain \\ ${ }^{\mathrm{d}}$ Department of Chemical and Pharmaceutical Sciences (DipSCF), University of Ferrara (UniFE), Via L. Borsari 46, Ferrara, 44121, Italy \\ ${ }^{\mathrm{e}}$ U.S. Geological Survey, Geosciences and Environmental Change Science Center, Denver, CO, 80232, USA
}

\section{A R T I C L E I N F O}

\section{Keywords:}

Cow milk whey

Goat milk whey

Toxic element

ICP-MS

ICP-SFMS

Geographical origin

\begin{abstract}
A B S T R A T
Multi-element analyses determine the content of 17 trace elements (Al, V, Cr, Mn, Fe, Co, Ni, Cu, Zn, As, Se, Sr, $\mathrm{Cd}, \mathrm{Cs}, \mathrm{Ba}, \mathrm{Pb}, \mathrm{U}$ ) and 14 rare earth elements (La, Ce, Pr, Nd, Sm, Eu, Gd, Tb, Dy, Ho, Er, Yb, Lu, Y) in whey samples from cow and goat milk by inductively coupled plasma mass spectrometry and inductively coupled plasma-sector field mass spectrometry. A total of 261 milk whey samples were collected from four locations in the Veneto region of northeastern (NE) Italy. These samples contain a wide range concentration of 17 trace elements $\left(0.06-1530 \mu \mathrm{g} \mathrm{kg}^{-1}\right)$ and 14 rare earth elements $\left(0.16-28.2 \mathrm{ng} \mathrm{kg}^{-1}\right)$ in whey samples, but do not reach toxic concentrations. Elemental fingerprinting of trace and rare earth elements in cow and goat milk whey provide information on the dairy quality and, as they reflect the local environmental conditions, result in an excellent indicator of their geographical origin.
\end{abstract}

\section{Introduction}

Milk and dairy products are an equilibrated mixture of macronutrients (lipids, proteins, carbohydrates) and micronutrients (vitamins, enzymes, and minerals), and are therefore an exceptional aspect of a daily human diet (Levkov et al., 2017; Özturan \& Atasever, 2018; Petrović, Savić, \& Petronijević, 2016). In recent years, the interest in the nutritional significance of milk has markedly intensified (Rivero Martino, Fernández Sánchez, \& Sanz Medel, 2000), resulting in increasing knowledge of how minerals (major and trace elements) significantly contribute to different human body functions. Depending on their chemical form, minerals can combine with several proteins and peptides to influence their absorption in the human body (Hoac et al., 2007), as well as associated biochemical and biological activity (Levkov et al., 2017; Özturan \& Atasever, 2018; Prashanth, Kattapagari, Chitturi, Baddam, \& Prasad, 2015). When these minerals are present at normal levels, they can help stabilize cellular structures, but insufficient concentrations of minerals can cause disorders and diseases (Prashanth et al., 2015), and substantial concentrations may be toxic.

Due to the importance of these minerals for human health, and their prevalence within dairy products, researchers are increasingly interested in whey as an ingredient in food. Milk whey is the liquid substance remaining during cheese production after the milk clots and casein are removed (Brandelli, Daroit, \& Folmer Corrêa, 2015). Whey is currently an underutilized ingredient but is one which has the potential to supplement food with macro and micronutrients. However, little is known

Abbreviations: AZ, Ai Zei; EC, European Commission; HREEs, Heavy Rare Earth Elements; ICP-SFMS, Inductively Coupled Plasma-Sector Field Mass Spectrometry;

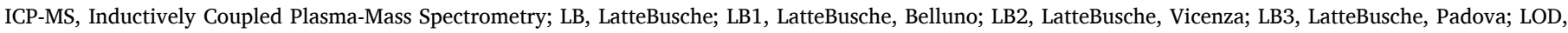

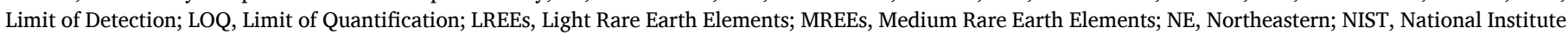

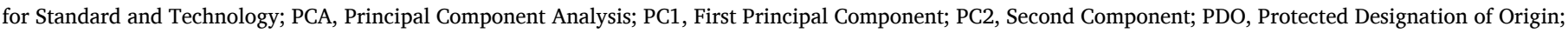

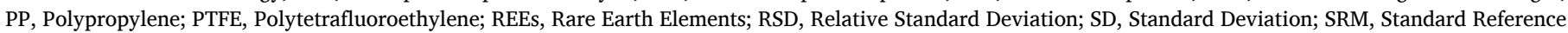
Material; TEs, Trace Elements; WHO, World Health Organization.

* Corresponding author. Department of Environmental Sciences, Informatics and Statistics (DAIS), Ca' Foscari University of Venice (UniVE), Via Torino 155, Venice-Mestre, 30172, Italy.

E-mail address: raffaello.tedesco@unive.it (R. Tedesco). 
regarding the distribution of trace elements (TEs) in whey (Hoac et al., 2007).

The content of mineral elements in milk is variable, due to the wide range of factors such as the lactation stage, nutritional status of the animal, environmental and genetic factors, content of elements in soil, industrial activities, and contaminated agricultural water used for irrigation (Esposito et al., 2017; Levkov et al., 2017; Licata et al., 2004; Malbe, Otstavel, Kodis, \& Viitak, 2010). The concentration of some elements (e.g. As, $\mathrm{Cd}, \mathrm{Hg}$, and $\mathrm{Pb}$ ) in milk provide direct evidence of the degree of contamination. Thus, these elements indicate the local or peripheral environmental conditions, including the quality of water, air, soil, and vegetation of the area where the cattle are located (González-Montaña, 2009).

The composition of most inorganic components present in the soil are directly related to the regional and local geology (Joebstl, Bandoniene, Meisel, \& Chatzistathis, 2010). Therefore, the determination of rare earth elements (REEs) can act as geochemical markers and can also provide a fingerprint for food traceability (Aceto et al., 2018; Bandoniene, Meisel, Rachetti, \& Walkner, 2018). For example, REEs supply information on the geographical origin of food products such as wine (Joebstl et al., 2010), rice, and tomatoes (Spalla et al., 2009). This multi-elemental composition of the soil and vegetation is then incorporated into animals that graze on local pastures (Danezis, Tsagkaris, Brusic, \& Georgiou, 2016).

During the past few years, REEs have been utilized in a number of industrial, medical and agricultural applications and consequently increase the associated impact related on human health.

(Pagano, Guida, Tommasi, \& Oral, 2015). Soil, vegetation, the atmosphere and water generally contain relatively low concentrations of REEs, where these REEs are also present at ultra-trace/trace concentrations (40-7970 $\mathrm{ng} \mathrm{kg}^{-1}$ ) in food (Spalla et al., 2009). However, due to their low mobility, the REEs present in these matrices can accumulate in the environment and bioaccumulate in biota.

(Li, Chen, Chen, \& Zhang, 2013). Thus, it is increasingly necessary to understand the biological role and behavior of these elements in systems such as plants and soil (Tyler, 2004).

Milk and milk products contain high concentrations $\left(\mathrm{mg} \mathrm{kg}^{-1}\right)$ of toxic trace elements as a result of increased anthropogenic pressure (industrial, agricultural and urban activities) on the environments in which cows, sheep, and goats are raised (Levkov et al., 2017). Metals are not biodegradable and can accumulate up the food chain through biotransformation, resulting in bioaccumulation and toxicity in biota and humans (Muhib et al., 2016). Animals assimilate trace metals from food and water, as well as inhaling contaminated atmospheric particulates (Esposito et al., 2017; Levkov et al., 2017; Muhib et al., 2016). Harmful metals, such as $\mathrm{Pb}, \mathrm{Cd}$, and As, can be transferred from animals to the human diet when people consume animal products from locations with contaminated soils, fodder, and/or pastures (González-Montaña, 2009).

The chemical and biological quality of the water used for irrigation in intensive agriculture can be compromised by industrial and agricultural contamination (Giusti \& Taylor, 2007). For instance, soils in the central part of the Veneto contain a range of potentially toxic elements such as $\mathrm{Al}, \mathrm{V}, \mathrm{Cr}, \mathrm{Ni}, \mathrm{Cd}, \mathrm{Pb}$. The sources of these contaminants are difficult to distinguish as they can derive from both anthropogenic origins (industrial activities and agricultural practices) and geogenic origins (Bini, Fontana, \& Spiandorello, 2013). Several studies evaluate toxic elements $(\mathrm{Cr}, \mathrm{As}, \mathrm{Cd}, \mathrm{Pb})$ in dairy products, carried out in different region of Italy and various countries, due to their human health risk (Ayar, Sert, \& Akin, 2009; Bini et al., 2013; Licata et al., 2012; Miedico, Tarallo, Pompa, \& Chiaravalle, 2016; Yüzbaşi, Sezgin, Yildirim, \& Yildirim, 2009). The World Health Organization (WHO) classifies TEs into essential, probably essential and toxic elements (World Health Organization, 1996).

While a few studies of TEs in milk whey exist (Rivero Martino et al., 2000; Rivero Martino, Fernández Sánchez, \& Sanz-Medel, 2001; Şanal,
Güler, \& Park, 2011), the literature does not contain research on REEs in milk or milk whey samples. To the best of our knowledge, this study is the first research on concentrations of both TEs and REEs content in milk whey produced in Italy. This study examines the concentrations of TEs and REEs in cow milk whey and goat milk whey, using the ICP-MS and ICP-SFMS, respectively to assess if the quality of milk whey differs based on the following factors:

(i) animal species,

(ii) potential release of elements during the production of dairy products, and

(iii) geographical area.

\section{Materials and methods}

\subsection{Instruments and materials}

Trace metal concentrations (Al, V, Cr, Mn, Fe, Co, Ni, Cu, Zn, As, Se, $\mathrm{Sr}, \mathrm{Cd}, \mathrm{Cs}, \mathrm{Ba}, \mathrm{Pb}, \mathrm{U}$ ) were determined using a coupled plasma ionization system inductively interfaced to a single quadrupole mass spectrometer (ICP-MS; 7500a, Agilent Technology Inc.), equipped with autosampler (ASX 520, Cetac, USA). Instrumental performances were monitored and verified before each analytical session through the acquisition of a $10 \mu \mathrm{g}$ $\mathrm{mL}^{-1}$ tuning solution containing ${ }^{7} \mathrm{Li},{ }^{89} \mathrm{Y},{ }^{205} \mathrm{Tl}$, and ${ }^{140} \mathrm{Ce}$. Optimization of instrumental performance has been improved by modifying the carrier gas flow (Ar gas 99.9999\%, SIAD, Bergamo, Italy), the sample flow rate, the torch position, and the lens voltage, thereby reducing the interferents (double-charged oxides and ions) to values less than 5\%, and consequently improving the instrumental sensitivity.

Before each analytical run, both internal and external standard solutions were prepared from the corresponding solutions by diluting with ultrapure water (resistivity at $18 \mathrm{M} \Omega \mathrm{cm}^{-1}$, Elga, Purelab ${ }^{\circledR}$ Chorus 2, United Kingdom). A multi-element standard solution (external standard), (10 $\mu \mathrm{g} \mathrm{m}^{-1}$, Ultra Scientific Inorganic Custom Standard 1208, North Kingstown, USA) consisting of 29 elements (Be, Li, Na, Mg, Al, K, $\mathrm{Ca}, \mathrm{V}, \mathrm{Cr}, \mathrm{Mn}, \mathrm{Fe}, \mathrm{Co}, \mathrm{Ni}, \mathrm{Cu}, \mathrm{Zn}, \mathrm{Ga}, \mathrm{As}, \mathrm{Se}, \mathrm{Rb}, \mathrm{Sr}, \mathrm{Ag}, \mathrm{Cd}$, In, Cs, Ba, Tl, $\mathrm{Pb}, \mathrm{Bi}, \mathrm{U}$ ) was employed. Twelve elements (Be, $\mathrm{Li}, \mathrm{Na}, \mathrm{Mg}, \mathrm{K}, \mathrm{Ca}, \mathrm{Ga}, \mathrm{Rb}$, $\mathrm{Ag}, \mathrm{In}, \mathrm{Tl}, \mathrm{Bi}$ ) were not analyzed, as they are not within the aims of the study. Trace element solutions for calibration curves were prepared in the range from $0.1 \mu \mathrm{g} \mathrm{L}^{-1}$ to $25 \mu \mathrm{g} \mathrm{L}^{-1}$. The internal standard solution of rhodium (Rh) (Inorganic Ventures, USA) was prepared according to the analytical needs from a stock solution of $10 \mu \mathrm{g} \mathrm{mL}^{-1}$ and analyzed at $100 \mu \mathrm{g} \mathrm{L}^{-1}$. Four $\mathrm{mL}$ of nitric acid $\left(\mathrm{HNO}_{3}\right)$ with a concentration of $65 \%$ (v/v) (Supra Pure grade, Romil Ltd, Cambridge, United Kingdom) was added into the sample vessel resulting in a final volume of $16 \mathrm{~mL}$. Standard Reference Material SRM-1846 infant formula milk purchased from the National Institute of Standards and Technology (NIST, Gaithersburg, MD, USA), served as the standard reference material, where $0.5 \mathrm{~g}$ was treated and analyzed such as other samples. This external standard was run once every 5 samples.

REE concentrations (La, Ce, Pr, Nd, Sm, Eu, Gd, Tb, Dy, Ho, Er, Yb, $\mathrm{Lu}, \mathrm{Y}$ ) were analyzed using an inductively coupled plasma-sector field plasma mass spectrometry (ICP-SFMS) (ElementXR; ThermoFinnigan, Bremen, Germany). The ICP-SFMS coupled with the APEX system (ESI,

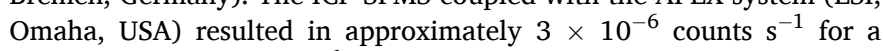
concentration of $1 \mu \mathrm{g} \mathrm{kg}^{-1}$ of In, depending on the tuning conditions. REE solutions for calibration curves were prepared in the range between $1 \mathrm{ng} \mathrm{kg}^{-1}$ to $10 \mathrm{ng} \mathrm{kg}^{-1}$. The signal intensities of the analytes were corrected for ${ }^{115} \mathrm{In}$, which was used as an internal reference standard. Table 1 demonstrates the instrumental and operational conditions for the ICP-MS and ICP-SFMS.

\subsection{Sample collection}

Cow and goat milk whey samples were collected from two farms, both located in the Veneto region of NE Italy (Fig. 1). The Ai Zei (AZ) 
Table 1

Instrumental parameters for ICP-MS and ICP-SFMS instruments.

\begin{tabular}{|c|c|c|c|}
\hline \multicolumn{4}{|c|}{ Instrumental parameters } \\
\hline \multicolumn{2}{|l|}{ ICP-MS (7500a) } & \multicolumn{2}{|c|}{ ICP-SFMS Element XR } \\
\hline RF power $(W)$ & 1500 & RF power $(W)$ & 1400 \\
\hline Interface & $\mathrm{Ni}$ cones & Cooling $\left(\mathrm{L} \min ^{-1}\right)$ & 16.0 \\
\hline Mass analyser & $\begin{array}{l}\text { Single } \\
\text { Quadrupole }\end{array}$ & $\begin{array}{l}\text { Auxiliary (L } \\
\min ^{-1} \text { ) }\end{array}$ & 0.97 \\
\hline $\begin{array}{l}\text { Ar-gas flow rates } \\
\qquad\left(\mathrm{L} \min ^{-1}\right)\end{array}$ & $\begin{array}{l}1.45 \\
\text { (optimized } \\
\text { daily) }\end{array}$ & $\begin{array}{l}\text { Nebulizer (L } \\
\min ^{-1} \text { ) }\end{array}$ & $0.8-1.1^{\mathrm{a}}$ \\
\hline $\begin{array}{l}\text { Nebulizer pump } \\
\text { rps }\end{array}$ & 0.10 & $\begin{array}{l}\text { Sweep gas (L } \\
\min ^{-1} \text { ) }\end{array}$ & $3.4-4.15^{\mathrm{a}}$ \\
\hline $\begin{array}{l}\text { Integration Time } \\
\text { sec }\end{array}$ & 0.10 & $\begin{array}{l}\text { Membrane } \\
\text { temperature }\left({ }^{\circ} \mathrm{C}\right)\end{array}$ & 175 \\
\hline $\begin{array}{l}\text { Injection time } \\
\text { sec }\end{array}$ & 0.72 & $\begin{array}{l}\text { Sample uptake } \\
\left(\mu \mathrm{L} \mathrm{min} \min ^{-1}\right)\end{array}$ & 100 \\
\hline Wash sec & 60 & $\begin{array}{l}\text { Resolution } \\
\left(\mathrm{m} \Delta \mathrm{m}^{-1}\right)\end{array}$ & 400 \\
\hline $\begin{array}{l}\text { Internal } \\
\text { standard }\end{array}$ & ${ }^{103} \mathrm{Rh}$ & Internal standard & ${ }^{115} \mathrm{In}$ \\
\hline $\begin{array}{l}\text { Spray chamber } \\
\text { temperature } \\
\left({ }^{\circ} \mathrm{C}\right)\end{array}$ & 4 & $\begin{array}{l}\text { Spray chamber } \\
\text { temperature }\left({ }^{\circ} \mathrm{C}\right)\end{array}$ & 95 \\
\hline \multirow[t]{3}{*}{$\begin{array}{l}\mathrm{n}^{\circ} \text { of replicates } \\
\text { per sample }\end{array}$} & 3 & $\begin{array}{l}\mathrm{n}^{\circ} \text { of replicates } \\
\text { per sample }\end{array}$ & 3 \\
\hline & & $\begin{array}{l}\text { Dwell time per } \\
\text { acquisition point } \\
\text { (ms) }\end{array}$ & 10 \\
\hline & & Selected isotopes & $\begin{array}{l}{ }^{89} \mathrm{Y},{ }^{139} \mathrm{La},{ }^{140} \mathrm{Ce},{ }^{141} \mathrm{Pr}, \\
{ }^{144} \mathrm{Nd},{ }^{151} \mathrm{Eu},{ }^{152} \mathrm{Sm}, \\
{ }^{160} \mathrm{Gd},{ }^{159} \mathrm{~Tb},{ }^{164} \mathrm{Dy}, \\
{ }^{165} \mathrm{Ho},{ }^{166} \mathrm{Er},{ }^{169} \mathrm{Tm}, \\
{ }^{172} \mathrm{Yb},{ }^{175} \mathrm{Lu}\end{array}$ \\
\hline
\end{tabular}

a Optimized to obtain maximum.

farm is located near the town of Belluno and uses goat milk to produce ricotta and other cheeses. LatteBusche (LB) is a cooperative with locations near Belluno (LB1), as well as the cities of Vicenza (LB2) and Padova (LB3). All LB locations use cow milk but create different products at different locations. For example, LB1 produces Piave and Montasio cheese, while both LB2 and LB3 produce Grana Padano cheese that meet the Protected Designation of Origin (PDO) criteria (Innocente \& Biasutti, 2013).

Sampling started during February 2017 and extended through June 2017. The process of collecting the milk whey samples was determined by the managers of the farms and was dependent upon the type and timing of cheese production. A total of 261 samples were collected for this study: 32 samples of goat milk whey from the AZ; and 71, 85 and 73 samples of cow milk whey from LB1, LB2, and LB3, respectively. Milk whey sampling was conducted three times a week at AZ, and six times a week at LB1, LB2 and LB3. Sample collection was carried out using 50 $\mathrm{mL}$ polypropylene (PP) tubes, previously cleaned with $2 \%(\mathrm{v} / \mathrm{v})$ of nitric acid for $24 \mathrm{~h}$ and rinsed with ultrapure water before use to reduce any exogenous contamination. Samples were stored at $-20{ }^{\circ} \mathrm{C}$ until their preparation for instrumental analyses. Before the mineralization treatment and chemical analysis, the milk whey samples, the standard solution and the certified reference materials were carefully weighed. Therefore, we evaluated the mass-volume ratio of the sample, and chose to express results using units of $\mathrm{mg} \mathrm{kg}^{-1}$ for a direct comparison with trace element values in similar matrices described in the literature.

\subsection{Sample preparation: microwave-assisted acid mineralization}

Chemical digestion was performed in closed vessels, where milk whey samples were completely digested using concentrated $\mathrm{HNO}_{3}(65 \%$ v/v, supra pure grade) and a microwave system (Milestone Ethos One, Sorisole, BG, Italy). Eight $\mathrm{mL}$ of fresh milk whey were placed into a polytetrafluoroethylene (PTFE) digestion vessel along with $4 \mathrm{~mL}$ of concentrated $\mathrm{HNO}_{3}(65 \%)$ and $4 \mathrm{~mL}$ of ultrapure water. Laboratory blanks were prepared by adding $4 \mathrm{~mL}$ of concentrated $\mathrm{HNO}_{3}(65 \%)$ and $12 \mathrm{~mL}$ of ultrapure water to reach the same volume of the milk whey samples. The microwave decomposed the samples using the following program: ramping up to $120^{\circ} \mathrm{C}$ in $5 \mathrm{~min}$ and then held at a constant temperature for $5 \mathrm{~min}$; ramping up from $120^{\circ} \mathrm{C}$ to $150{ }^{\circ} \mathrm{C}$ in $5 \mathrm{~min}$ and remaining at $150{ }^{\circ} \mathrm{C}$ for $5 \mathrm{~min}$; and finally cooling down to room temperature within $20 \mathrm{~min}$. After this mineralization process, the digested samples were left to cool and then were transferred into acid-cleaned 50 $\mathrm{mL}$ PP tubes. Finally, the samples were refrigerated at $-20^{\circ} \mathrm{C}$, stored in the dark and diluted with ultrapure water immediately before starting

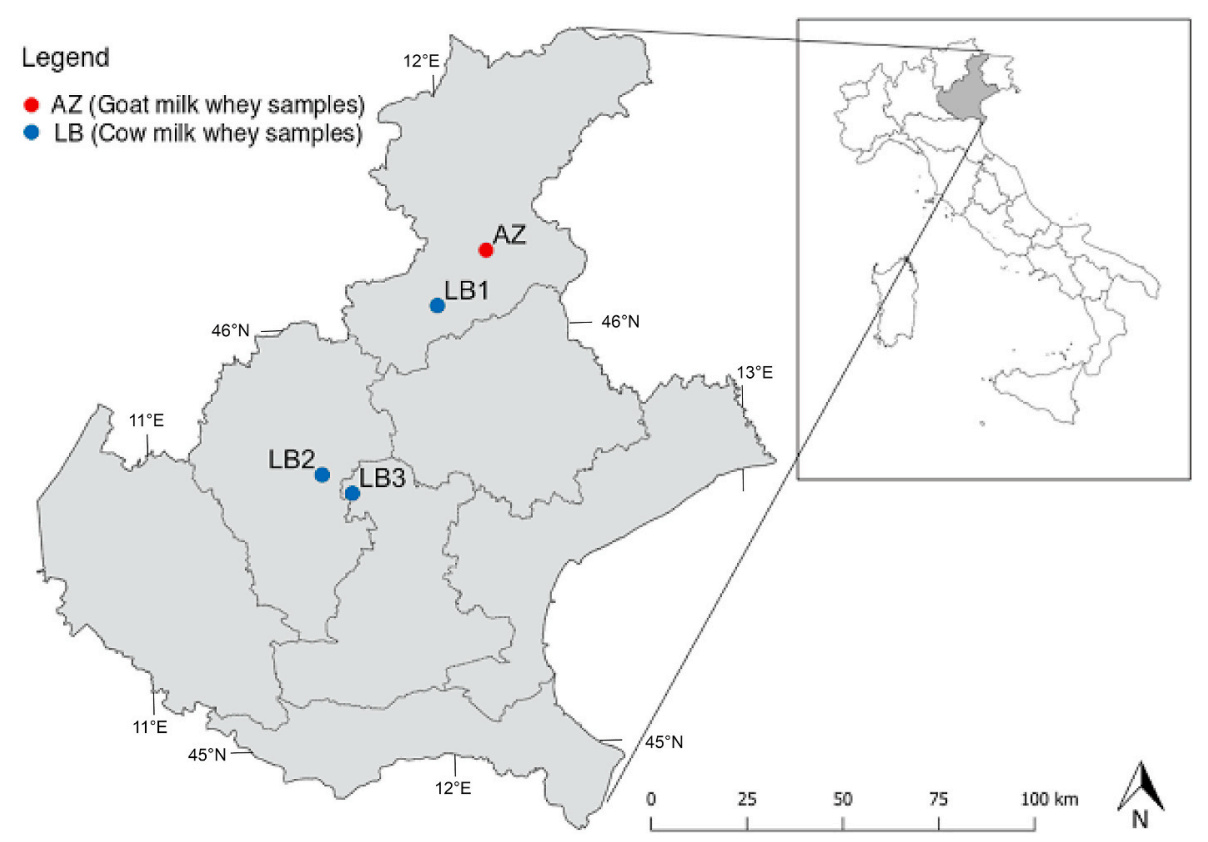

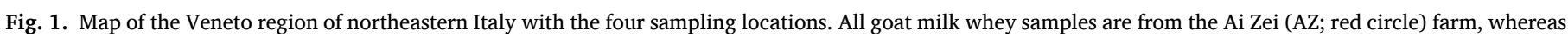

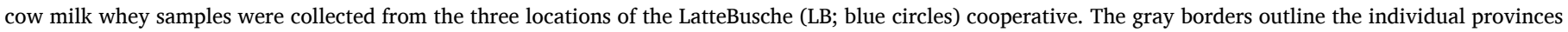
within the Veneto region. 
the instrumental analysis by ICP-MS and ICP-SFMS.

\subsection{Quality assurance}

Analytical parameters such as linearity, limit of detection (LOD) and limit of quantification (LOQ) were evaluated (Table 2). LODs and LOQs were determined as 3 times the standard deviation and 10 times the standard deviation of the intensity of the 10 laboratory blanks for each element, respectively. The linearity was assessed by examining eight points covering a concentration range from 0.1 to $25 \mu \mathrm{g} \mathrm{L}^{-1}$ of each element. The precision of the method is determined by the relative standard deviation (RSD) which ranges between $6.6 \%$ and $10 \%$.

The standard reference material, SRM-1846 infant formula milk (NIST), was stored at $-18^{\circ} \mathrm{C}$ before use. This reference material offers certified values for trace elements including $\mathrm{Mn}, \mathrm{Fe}, \mathrm{Cu}, \mathrm{Zn}$ and $\mathrm{Se}$. We evaluated the accuracy of the analytical method by treating, processing, and analyzing the standard reference material in the same way as the sample. Table 2 reports the mean elemental concentrations from triplicate analysis of the certified material. Regression coefficients $\left(R^{2}\right)$ with results up to 0.96 indicated good linearity. Element recovery was determined by adding the multi-elemental standard with a concentration of $10 \mu \mathrm{g} \mathrm{L}^{-1}$ to the milk whey samples. The average elemental recovery in the matrix ranged between $75 \%$ and $98 \%$.

LODs and LOQs of REEs were calculated in the same way as for the TEs as well as in six blank samples. LOD ranged from $0.09 \mathrm{ng} \mathrm{kg}^{-1}(\mathrm{Ho})$ to $11.5 \mathrm{ng} \mathrm{kg}^{-1}$ (Ce), while LOQ ranged from $0.30 \mathrm{ng} \mathrm{kg}^{-1}$ (Ho) to 38.2 $\mathrm{ng} \mathrm{kg}{ }^{-1}(\mathrm{Ce})$. The REE $\mathrm{R}^{2}$ values ranged between 0.89 and 0.98 .

\subsection{Statistical analysis}

The multi-elemental profiles and different sampling periods were

Table 2

Validation parameters for trace elements and standard reference material analysis.

\begin{tabular}{|c|c|c|c|c|c|c|}
\hline \multirow[t]{2}{*}{ Element } & \multirow[t]{2}{*}{$\begin{array}{l}(\mathrm{mg} \\
\left.\mathrm{kg}^{-1}\right)\end{array}$} & \multirow[t]{2}{*}{$\begin{array}{l}\text { LOQ } \\
(\mathrm{mg} \\
\left.\mathrm{kg}^{-1}\right)\end{array}$} & \multirow[t]{2}{*}{$\begin{array}{l}\text { Correlation } \\
\text { Coefficient } \\
\left(\mathrm{R}^{2}\right)\end{array}$} & \multirow[t]{2}{*}{$\begin{array}{l}\text { RSD } \\
\%+ \\
(\mathrm{n} \\
= \\
10) \\
\mathrm{c}\end{array}$} & $\begin{array}{l}\text { NIST } \\
\text { SRM- } \\
1846 \\
\text { Infant } \\
\text { Formula }\end{array}$ & $\begin{array}{l}\text { NIST } \\
\text { SRM- } \\
1846 \\
\text { Infant } \\
\text { Formula }\end{array}$ \\
\hline & & & & & $\begin{array}{l}\text { Certified } \\
\text { value } \pm \mathrm{U} \\
{ }^{\mathrm{b}}(\mathrm{mg} \\
\left.\mathrm{kg}^{-1}\right)\end{array}$ & $\begin{array}{l}\text { Found } \\
\text { value } \pm \\
\mathrm{SD}^{\mathrm{d}}(\mathrm{mg} \\
\left.\mathrm{kg}^{-1}\right)\end{array}$ \\
\hline V & 0.0002 & 0.0005 & 0.9962 & 9.3 & - & - \\
\hline $\mathrm{Mn}$ & 0.0007 & 0.002 & 0.9990 & 6.7 & $0.4^{\mathrm{a}}$ & $\begin{array}{l}0.41 \pm \\
0.07\end{array}$ \\
\hline $\mathrm{Fe}$ & 0.3 & 0.9 & 0.9989 & 6.6 & $\begin{array}{l}63.1 \pm \\
4.0\end{array}$ & $\begin{array}{l}60.5 \pm \\
1.6\end{array}$ \\
\hline Co & 0.00007 & 0.0002 & 0.9989 & 7.6 & - & - \\
\hline $\mathrm{Cu}$ & 0.001 & 0.004 & 0.9600 & 8.1 & $\begin{array}{l}5.04 \pm \\
0.27\end{array}$ & $\begin{array}{l}4.80 \pm \\
0.45\end{array}$ \\
\hline $\mathrm{Zn}$ & 0.00007 & 0.0003 & 0.9988 & 8.3 & $\begin{array}{l}60.0 \pm \\
3.2\end{array}$ & $\begin{array}{l}58.4 \pm \\
2.0\end{array}$ \\
\hline $\mathrm{Se}$ & 0.007 & 0.02 & 0.9987 & 7.1 & $0.08^{a}$ & $\begin{array}{l}0.074 \pm \\
0.005\end{array}$ \\
\hline $\mathrm{Al}$ & 0.009 & 0.03 & 0.9990 & 8.5 & - & - \\
\hline $\mathrm{Cr}$ & 0.0011 & 0.004 & 0,9992 & 7.0 & - & - \\
\hline $\mathrm{Ni}$ & 0.0005 & 0.002 & 0.9996 & 9.0 & - & - \\
\hline $\mathrm{Sr}$ & 0.00008 & 0.0003 & 0.9993 & 7.4 & - & - \\
\hline $\mathrm{U}$ & 0.00003 & 0.00009 & 0.9994 & 7.7 & - & - \\
\hline As & 0.0007 & 0.0023 & 0.9996 & 10 & - & - \\
\hline $\mathrm{Cd}$ & 0.0004 & 0.001 & 0.9989 & 7.8 & - & - \\
\hline $\mathrm{Pb}$ & 0.00008 & 0.0003 & 0.9998 & 9.6 & - & - \\
\hline $\mathrm{Ba}$ & 0.0003 & 0.001 & 0.9999 & 8.8 & - & - \\
\hline Cs & 0.00004 & 0.0001 & 0.9979 & 8.1 & - & - \\
\hline
\end{tabular}

\footnotetext{
${ }^{\mathrm{a}}$ Information value.

$\mathrm{b}$ Uncertainty of the certified value.

${ }^{c}$ Relative standard deviation.

${ }^{\mathrm{d}}$ Standard deviation.
}

both examined using principal component analysis (PCA; Fig. 2). Each element was expressed as their mean and corresponding standard deviation. PCA is a chemometric technique which is commonly used for multidimensional evaluation of data sets. This technique reduces the dimensionality of data sets with minimal loss of important information from the original data (Rodríguez-Bermúdez et al., 2018).

\section{Results and discussion}

Table 3 depicts the concentrations of TEs and REEs in goat milk whey (AZ) and cow milk whey (LB1, LB2 and LB3) samples from the Veneto region of NE Italy. The mean concentrations and standard deviations of 17 TEs (Al, V, Cr, Mn, Fe, Co, Ni, Cu, Zn, As, Se, Sr, Cd, Cs, Ba, Pb, U) result from ICP-MS analysis and 14 REEs (La, Ce, Pr, Nd, Sm, Eu, Gd, Tb, $\mathrm{Dy}, \mathrm{Ho}, \mathrm{Er}, \mathrm{Yb}, \mathrm{Lu}, \mathrm{Y}$ ) derive from ICP-SFMS analysis. We compare the results from each element against the same element from the four locations (AZ, LB1, LB2, and LB3) and two types of milk whey. Only a few previous investigations of trace elements in milk whey exist (Rivero Martino et al., 2001; Şanal et al., 2011). We compare our results with the available previous studies that investigated the elemental concentrations of cow and goat milk whey (Table 4).

\subsection{Essential trace elements}

\subsubsection{Iron ( $\mathrm{Fe})$}

Iron is the most abundant trace element in both the cow milk whey (LB1, LB2, and LB3) and goat milk whey (AZ) samples. The mean Fe concentration in goat milk whey samples from AZ is $1.53 \mathrm{mg} \mathrm{kg}{ }^{-1}$, which is 5 times greater than Fe concentrations in other goat milk whey studies from samples in the Canary Islands (Herrera García et al., 2006). The cow milk whey samples from the LatteBusche cooperative locations LB1, LB2, and LB3 have mean Fe concentrations of 0.64, 0.34, and 0.70 $\mathrm{mg} \mathrm{kg}^{-1}$, respectively, which are greater than the majority of cow milk whey Fe concentrations reported in the literature (Reykdal, Rabieh, Steingrimsdottir, \& Gunnlaugsdottir, 2011; Rivero Martino et al., 2001, 2000). However, Yüzbaşi et al. (2009), determine Fe concentrations of $2.5 \mathrm{mg} \mathrm{kg}^{-1}$, which is 3-7 times higher than the Fe concentrations in this study.

\subsubsection{Aluminium (Al)}

The mean goat milk whey $\mathrm{Al}$ concentrations $\left(0.019 \mathrm{mg} \mathrm{kg}^{-1}\right)$ are substantially less than the only published results of $\mathrm{Al}\left(4.94 \mathrm{mg} \mathrm{kg}^{-1}\right)$ in similar samples (Şanal et al., 2011). However, the mean Al concentration of our goat milk whey samples is quite similar to the mean Al concentrations from cow milk whey samples obtained from the LB2 and LB3 locations in this study ( 0.016 and $0.019 \mathrm{mg} \mathrm{kg}^{-1}$, respectively). Cow milk whey samples from LB1 have a mean concentration of $0.035 \mathrm{mg}$ $\mathrm{kg}^{-1}$, which is approximately double the values at the LB2 and LB3 locations. This result may be due to effects from the pasteurization process on $\mathrm{Al}$ in the industrial containers and/or packaging (Coni et al., 1996). Our results are the first analysis of $\mathrm{Al}$ concentrations in cow milk whey samples, and therefore it is not possible to compare these results with other research.

\subsubsection{Copper (Cu)}

Our work is also the first to determine $\mathrm{Cu}$ concentrations in goat milk whey, with mean concentrations of $0.023 \mathrm{mg} \mathrm{kg}^{-1}$. Mean Cu concentrations in cow milk whey $\left(0.024,0.17\right.$, and $0.26 \mathrm{mg} \mathrm{kg}^{-1}$, in LB1, LB2 and LB3, respectively) are higher than the results reported in most other cow milk whey studies (Table 3), with the exception of the cow milk whey $\mathrm{Cu}$ concentrations of $0.05 \mathrm{mg} \mathrm{kg}^{-1}$ reported by Castro-González et al. (2018). The Cu concentrations in both LB2 and LB3 were about ten times higher than the values reported for AZ and LB1, where these two locations have almost equivalent concentrations. A previous study attributes the high $\mathrm{Cu}$ values in cheese production to the use of traditional copper containers (Coni et al., 1996). Subsequent research (Lante, 


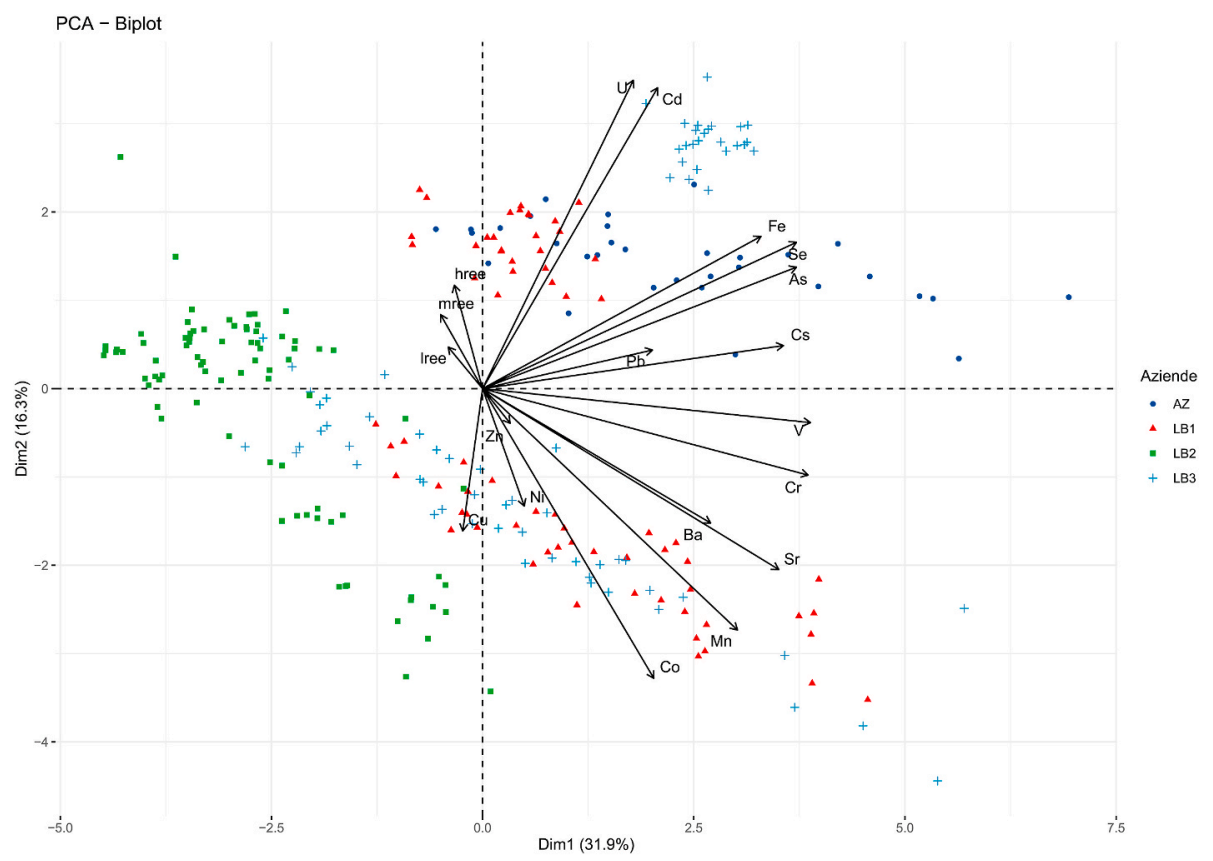

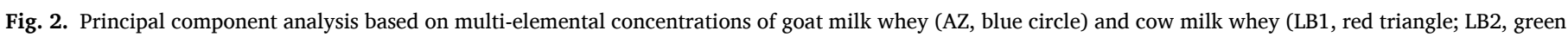
square; LB3, light blue cross) samples.

Lomolino, Cagin \& Spettoli, 2006) builds up on this initial investigation (Coni et al., 1996) and ascribes increased $\mathrm{Fe}, \mathrm{Al}$, and $\mathrm{Cu}$ concentrations in milk samples to the release of these elements from metal containers and tools, which are often used at high temperatures during dairy product processes. The similar concentrations of $\mathrm{Cu}$ in AZ and LB1 samples may be partially due to the fact that both farms are located in the same geographical area (Fig. 1).

\subsubsection{Zinc (Zn)}

The zinc content in goat milk whey samples from AZ have mean concentrations $\left(0.025 \mathrm{mg} \mathrm{kg}^{-1}\right) 50$ times less than the only other published goat milk whey value of $\left(1.20 \mathrm{mg} \mathrm{kg}^{-1}\right)$ (Herrera García et al., 2006). The mean $\mathrm{Zn}$ values in cow milk whey $(0.166,0.088$, and 0.100 $\mathrm{mg} \mathrm{kg}^{-1}$, from LB1, LB2, and LB3, respectively) are similar to the values of 0.23 and $0.13 \mathrm{mg} \mathrm{kg}^{-1}$ from other studies (Castro-González et al., 2018; Reykdal et al., 2011). However, all of these results are approximately 10 times less than values $\left(1.2\right.$ and $\left.2.2 \mathrm{mg} \mathrm{kg}^{-1}\right)$ obtained by Yüzbaşi et al. (2009). In our study, the Zn concentrations in the goat milk whey samples were consistently less than values from cow milk whey samples. This difference in mean values of $\mathrm{Zn}$ content may be due to physiological peculiarities of two animal species (Miedico et al., 2016).

\subsubsection{Selenium (Se)}

The concentration of selenium in milk may depend on the content and availability of this element in animal feed (Reykdal et al., 2011), and therefore may substantially differ by location and diet, even within samples from the same species. The Se concentrations in goat milk samples from AZ $\left(0.043 \mathrm{mg} \mathrm{kg}^{-1}\right)$ are 10 times higher than values (4.86 $\mu \mathrm{g} \mathrm{kg}^{-1}$ ) reported by Herrera García et al. (2006). Our cow milk whey results are also substantially higher than concentrations in previous work (Reykdal et al., 2011; Rivero Martino et al., 2000). The LB1 and LB3 concentrations of 0.041 and $0.047 \mathrm{mg} \mathrm{kg}^{-1}$ are 10 times higher than the values of $0.63 \mu \mathrm{g} 100 \mathrm{~g}^{-1}$ and $4.1 \mu \mathrm{g} \mathrm{L}{ }^{-1}$ (Reykdal et al., 2011; Rivero Martino et al., 2000), while the LB2 concentrations $(0.027 \mathrm{mg}$ $\mathrm{kg}^{-1}$ ) are approximately 5 times higher than the values reported in the available literature (Table 4).

\subsubsection{Vanadium $(V)$}

Mean $\mathrm{V}$ concentrations in goat milk whey samples $\left(0.0050 \mathrm{mg} \mathrm{kg}^{-1}\right)$ are 200 times lower than the lone data described in the literature (Şanal et al., 2011). As this study and the results from (Şanal et al., 2011) are the only examinations of $\mathrm{V}$ in goat milk whey, it is not possible to know if either result is similar to a general mean value of $\mathrm{V}$ concentrations in goat milk whey from locations across the globe. Our results of $\mathrm{V}$ concentrations in cow milk whey are $0.046,0.019$, and $0.034 \mathrm{mg} \mathrm{kg}^{-1}$ in LB1, LB2, and LB3, respectively. Our obtained results of V concentrations indicate similar values in AZ, LB1, and LB3, while the mean value in LB2 was about half those from the other three locations.

\subsubsection{Strontium (Sr)}

Strontium was detected in all milk whey samples. The mean $\mathrm{Sr}$ concentration in AZ samples is $0.089 \mathrm{mg} \mathrm{kg}^{-1}$, which to the best of our knowledge, is the first examination of Sr in goat milk whey. The mean $\mathrm{Sr}$ concentrations from LB2 $\left(0.048 \mathrm{mg} \mathrm{kg}^{-1}\right)$ are only half that of the values from LB1 and LB3 (0.084 and $\left.0.095 \mathrm{mg} \mathrm{kg}^{-1}\right)$, where LB1 and LB3 are themselves 3 times less than the mean concentrations $(0.274$ and 0.270 $\mathrm{mg} \mathrm{kg}^{-1}$ ) found by Rivero Martino et al. (2000) and Rivero Martino et al. (2001). In our study, the Sr values in goat milk whey samples (AZ) are comparable to cow milk whey samples from LB1 and LB3, demonstrating a similarity in $\mathrm{Sr}$ concentrations regardless of species. The concentration of $\mathrm{Sr}$ in milk depends on the ability of plants to absorb this element and the transfer of $\mathrm{Sr}$ to cattle either through grazing or lactation (Levkov et al., 2017; Petrović et al., 2016). The Quaternary sediments of the Veneto region contain relatively high $\mathrm{Sr}$ concentrations from input from the neighbouring Dolomites (Poto et al., 2013 and references therein).

\subsubsection{Other trace elements}

This research is the first work to investigate manganese (Mn), cobalt (Co), cesium (Cs), and barium (Ba) concentrations in cow milk whey and goat milk whey. The concentrations of each element are similar to each other in both types of milk whey samples for all four of these elements, but especially for Mn and Co (Table 3). The barium level in the goat milk whey samples contains a slightly lower concentration than cow milk whey samples, while the Cs concentrations in goat milk whey samples 
Table 3

Trace element and rare earth element concentrations determined in two types of milk whey samples from four locations across the Veneto region of northeastern Italy. Data are reported as mean \pm SD (standard deviation), where TE concentrations are in $\mathrm{mg} \mathrm{kg}^{-1}$ (wet weight), and REE concentrations are in $\mathrm{ng} \mathrm{kg}^{-1}$.

\begin{tabular}{|c|c|c|c|c|}
\hline \multirow[t]{2}{*}{ Farm } & \multicolumn{2}{|l|}{ Ai Zei } & \multicolumn{2}{|l|}{ LatteBusche (LB) } \\
\hline & $\begin{array}{l}\text { Goat milk } \\
\text { whey }(A Z) n= \\
32\end{array}$ & $\begin{array}{l}\text { Cow milk } \\
\text { whey (LB1) n } \\
=71\end{array}$ & $\begin{array}{l}\text { Cow milk } \\
\text { whey (LB2) n } \\
=85\end{array}$ & $\begin{array}{l}\text { Cow milk } \\
\text { whey (LB3) n } \\
=73\end{array}$ \\
\hline $\begin{array}{l}\text { Trace } \\
\text { Element }\end{array}$ & $\begin{array}{l}\operatorname{mean} \pm S D \\
\left(\mathrm{mg} \mathrm{kg}^{-1}\right)\end{array}$ & $\begin{array}{l}\operatorname{mean} \pm S D \\
\left(\mathrm{mg} \mathrm{kg}{ }^{-1}\right)\end{array}$ & $\begin{array}{l}\operatorname{mean} \pm S D \\
\left(\mathrm{mg} \mathrm{kg}^{-1}\right)\end{array}$ & $\begin{array}{l}\operatorname{mean} \pm S D \\
\left(\mathrm{mg} \mathrm{kg}^{-1}\right)\end{array}$ \\
\hline $\mathrm{V}$ & $\begin{array}{l}0.0050 \pm \\
0.0015\end{array}$ & $\begin{array}{l}0.0046 \pm \\
0.0007\end{array}$ & $\begin{array}{l}0.0019 \pm \\
0.0012\end{array}$ & $\begin{array}{l}0.0034 \pm \\
0.0009\end{array}$ \\
\hline $\mathrm{Mn}$ & $\begin{array}{l}0.0044 \pm \\
0.0012\end{array}$ & $\begin{array}{l}0.0047 \pm \\
0.0017\end{array}$ & $\begin{array}{l}0.0035 \pm \\
0.0008\end{array}$ & $\begin{array}{l}0.0046 \pm \\
0.0017\end{array}$ \\
\hline $\mathrm{Fe}$ & $1.53 \pm 0.09$ & $0.64 \pm 0.10$ & $0.34 \pm 0.12$ & $0.70 \pm 0.30$ \\
\hline Co & $\begin{array}{l}0.0007 \pm \\
0.0001\end{array}$ & $\begin{array}{l}0.0012 \pm \\
0.0004\end{array}$ & $\begin{array}{l}0.0009 \pm \\
0.0004\end{array}$ & $\begin{array}{l}0.0011 \pm \\
0.0003\end{array}$ \\
\hline $\mathrm{Cu}$ & $0.023 \pm 0.014$ & $0.024 \pm 0.009$ & $0.17 \pm 0.06$ & $0.26 \pm 0.1$ \\
\hline $\mathrm{Zn}$ & $0.025 \pm 0.015$ & $0.166 \pm 0.074$ & $0.088 \pm 0.021$ & $0.100 \pm 0.032$ \\
\hline Se & $0.043 \pm 0.005$ & $0.041 \pm 0.007$ & $0.027 \pm 0.006$ & $0.047 \pm 0.014$ \\
\hline $\mathrm{Al}$ & $0.019 \pm 0.018$ & $0.035 \pm 0.024$ & $0.016 \pm 0.016$ & $0.019 \pm 0.017$ \\
\hline $\mathrm{Cr}$ & $0.027 \pm 0.006$ & $0.027 \pm 0.004$ & $0.016 \pm 0.008$ & $0.025 \pm 0.005$ \\
\hline $\mathrm{Ni}$ & $0.009 \pm 0.004$ & $0.01 \pm 0.005$ & $0.008 \pm 0.004$ & $0.007 \pm 0.002$ \\
\hline $\mathrm{Sr}$ & $0.089 \pm 0.029$ & $0.084 \pm 0.025$ & $0.048 \pm 0.011$ & $0.095 \pm 0.027$ \\
\hline $\mathrm{U}$ & $\begin{array}{l}0.00010 \pm \\
0.00002\end{array}$ & $\begin{array}{l}0.00009 \pm \\
0.00004\end{array}$ & $\begin{array}{l}0.00006 \pm \\
0.00002\end{array}$ & $\begin{array}{l}0.00010 \pm \\
0.00007\end{array}$ \\
\hline As & $\begin{array}{l}0.0099 \pm \\
0.0042\end{array}$ & $\begin{array}{l}0.0062 \pm \\
0.0010\end{array}$ & $\begin{array}{l}0.0039 \pm \\
0.0008\end{array}$ & $\begin{array}{l}0.0067 \pm \\
0.0019\end{array}$ \\
\hline $\mathrm{Cd}$ & $\begin{array}{l}0.0013 \pm \\
0.0001\end{array}$ & $\begin{array}{l}0.0013 \pm \\
0.0005\end{array}$ & $\begin{array}{l}0.0009 \pm \\
0.0002\end{array}$ & $\begin{array}{l}0.0014 \pm \\
0.0009\end{array}$ \\
\hline $\mathrm{Pb}$ & $\begin{array}{l}0.0015 \pm \\
0.0018\end{array}$ & $\begin{array}{l}0.0002 \pm \\
0.0001\end{array}$ & $\begin{array}{l}0.0002 \pm \\
0.0001\end{array}$ & $\begin{array}{l}0.0003 \pm \\
0.0002\end{array}$ \\
\hline $\mathrm{Ba}$ & $0.003 \pm 0.001$ & $0.006 \pm 0.002$ & $0.003 \pm 0.001$ & $0.006 \pm 0.001$ \\
\hline Cs & $\begin{array}{l}0.0071 \pm \\
0.0019\end{array}$ & $\begin{array}{l}0.0037 \pm \\
0.0008\end{array}$ & $\begin{array}{l}0.0023 \pm \\
0.0004\end{array}$ & $\begin{array}{l}0.0052 \pm \\
0.0014\end{array}$ \\
\hline $\begin{array}{l}\text { Rare Earth } \\
\text { Element }\end{array}$ & $\begin{array}{l}\text { mean } \pm \text { SD } \\
\left(\mathrm{ng} \mathrm{kg}^{-1}\right)\end{array}$ & $\begin{array}{l}\operatorname{mean} \pm \mathrm{SD} \\
\left(\mathrm{ng} \mathrm{kg}^{-1}\right)\end{array}$ & $\begin{array}{l}\text { mean } \pm \mathrm{SD} \\
\left(\mathrm{ng} \mathrm{kg}^{-1}\right)\end{array}$ & $\begin{array}{l}\operatorname{mean} \pm S D \\
\left(\mathrm{ng} \mathrm{kg}^{-1}\right)\end{array}$ \\
\hline $\mathrm{La}$ & $7.11 \pm 6.26$ & $6.40 \pm 7.11$ & $5.91 \pm 9.16$ & $14.1 \pm 16.4$ \\
\hline $\mathrm{Ce}$ & $12.7 \pm 12.4$ & $10.8 \pm 12.1$ & $19.2 \pm 21.9$ & $28.2 \pm 22.9$ \\
\hline $\operatorname{Pr}$ & $3.92 \pm 4.26$ & $2.99 \pm 3.60$ & $9.25 \pm 7.05$ & $12.5 \pm 11.3$ \\
\hline Nd & $4.46 \pm 3.55$ & $3.65 \pm 3.45$ & $3.77 \pm 6.53$ & $9.9 \pm 12.7$ \\
\hline $\mathrm{Sm}$ & $4.89 \pm 4.47$ & $4.25 \pm 4.22$ & $9.61 \pm 9.16$ & $16.0 \pm 20.2$ \\
\hline $\mathrm{Eu}$ & $1.29 \pm 1.44$ & $0.95 \pm 1.01$ & $3.41 \pm 2.92$ & $3.50 \pm 2.55$ \\
\hline Gd & $0.90 \pm 0.68$ & $0.68 \pm 0.63$ & $3.11 \pm 3.00$ & $2.92 \pm 2.69$ \\
\hline $\mathrm{Tb}$ & $2.77 \pm 0.67$ & $10.2 \pm 15.6$ & $21.7 \pm 15.4$ & $36.4 \pm 13.7$ \\
\hline Dy & $1.07 \pm 1.10$ & $0.74 \pm 0.84$ & $1.20 \pm 4.12$ & $1.67 \pm 1.63$ \\
\hline Ho & $0.23 \pm 0.23$ & $0.16 \pm 0.15$ & $1.03 \pm 1.10$ & $0.82 \pm 0.91$ \\
\hline Er & $0.43 \pm 0.62$ & $0.25 \pm 0.36$ & $1.58 \pm 1.61$ & $1.61 \pm 1.34$ \\
\hline $\mathrm{Yb}$ & $0.65 \pm 0.74$ & $0.38 \pm 0.36$ & $1.35 \pm 1.69$ & $1,64 \pm 1.79$ \\
\hline $\mathrm{Lu}$ & $2.36 \pm 0.44$ & $7.10 \pm 10.6$ & $17.8 \pm 12.7$ & $28.0 \pm 9.7$ \\
\hline $\mathrm{Y}$ & $10.1 \pm 9.5$ & $5.48 \pm 6.40$ & $17.3 \pm 18.6$ & $18.8 \pm 15.0$ \\
\hline
\end{tabular}

are consistently slightly higher than all the Cs values in cow milk whey samples.

\subsection{Toxic trace elements}

Certain trace elements, such as $\mathrm{Cr}$, As, $\mathrm{Cd}$, and $\mathrm{Pb}$, are risks to human health due to their strong toxicity. These elements can accumulate in both plants and animals and can be ingested by people. Currently, European legislation (E.C. Regulation, 2006) does not set a maximum limit for most heavy metals in milk and dairy products. The only exception is $\mathrm{Pb}$, which has an upper limit of $0.02 \mathrm{mg} \mathrm{kg}^{-1}$ in raw milk and milk used for dairy products.

\subsubsection{Lead $(\mathrm{Pb})$}

Our results demonstrate differences between goat milk whey and cow milk whey $\mathrm{Pb}$ concentrations, as well as substantially lower $\mathrm{Pb}$ concentrations in all samples from the Veneto region compared to samples from elsewhere in the world. The $\mathrm{Pb}$ concentrations of goat milk whey samples from AZ were consistently higher than the cow milk whey samples from LB1, LB2, and LB3. The AZ mean $\mathrm{Pb}$ concentrations of $0.0015 \mathrm{mg} \mathrm{kg}^{-1}$, are more than 1000 times lower than the mean concentration (1.92 mg kg${ }^{-1}$ ) of samples from Turkey (Şanal et al., 2011). The mean Pb concentrations in LB1, LB2, and LB3 (0.0002, 0.0002, and $0.0003 \mathrm{mg} \mathrm{kg}^{-1}$, respectively) are similar to each other (Table 4), yet lower than other values in the literature and results from the Food Agricultural Organization and World Health Organization (Castro-González et al., 2018; FAO, WHO, \& JEFCA, 2011; Rivero Martino et al., 2000; Yüzbaşi et al., 2009).

\subsubsection{Cadmium (Cd)}

The mean concentration of $\mathrm{Cd}$ in samples from the AZ farm $(0.0013$ $\left.\mathrm{mg} \mathrm{kg}^{-1}\right)$ is 40 times lower than the values $\left(0.05 \mathrm{mg} \mathrm{kg}^{-1}\right)$ from Turkey reported by Şanal et al. (2011). The mean Cd concentrations of $\mathrm{Cd}$ in LB1, LB2, and LB3 (0.0013, 0.0009, and $0.0014 \mathrm{mg} \mathrm{kg}^{-1}$, respectively) are quite similar to each other, but all are 3 times less than the value (0.0037 $\mathrm{mg} \mathrm{kg}^{-1}$ ) from Ankara, Turkey reported in the literature (Yüzbaşi et al., 2009). The mean values of Cd in milk whey are similar between samples from both of the 2 species of animals. This similarity is surprising as metal containers and tools used for processing milk at high temperatures can release $\mathrm{Cd}$, resulting in varying Cd concentrations in the milk (Coni, Bocca, Ianni, \& Caroli, 1995). Industrial emissions, and/or agricultural activities, such as the use of fertilizers, are also responsible for emitting toxic elements including $\mathrm{Cd}$ and $\mathrm{Pb}$ into the food chain and eventually into products for human consumption (Lante, Lomolino, Cagnin, \& Spettoli, 2006; Licata et al., 2004).

\subsubsection{Chromium (Cr)}

The $\mathrm{Cr}$ concentrations are remarkably similar for all locations and milk types in this study. Goat milk whey samples from the AZ location have mean $\mathrm{Cr}$ concentrations $\left(0.027 \mathrm{mg} \mathrm{kg}^{-1}\right)$ identical to and/or similar to cow milk whey mean $\mathrm{Cr}$ concentrations of $0.027,0.016$, and $0.025 \mathrm{mg} \mathrm{kg}^{-1}$ from the LB1, LB2, and LB3 locations, respectively. The $\mathrm{Cr}$ concentrations from all of the samples in this study are similar to $\mathrm{Cr}$ concentrations from cow milk whey samples in the only other study of this type from Puebla, Mexico (see Table 4) (Castro-González et al., 2018).

\subsubsection{Arsenic (As)}

In this study, the As values are substantially less than As concentrations determined in other investigations (Tables 3 and 4). Mean As concentrations $\left(0.0099 \mathrm{mg} \mathrm{kg}^{-1}\right)$ from goat milk whey in AZ samples $\left(0.0099 \mathrm{mg} \mathrm{kg}^{-1}\right)$ are approximately 200 times less than the value $(1.96$ $\mathrm{mg} \mathrm{kg}^{-1}$ ) reported in a previous investigation from Turkey (Şanal et al., 2011). The mean cow milk whey samples also have substantially lower concentrations $\left(0.0062,0.0039\right.$, and $0.0067 \mathrm{mg} \mathrm{kg}^{-1}$ from LB1, LB2, and LB3, respectively) than As concentrations $\left(0.52 \mathrm{mg} \mathrm{kg}^{-1}\right)$ from Mexico (Castro-González et al., 2018). The As values from LB1 and LB3 samples are similar to one another, whereas they are twice as high as mean As concentrations from LB2 $\left(0.0039 \mathrm{mg} \mathrm{kg}^{-1}\right)$. Low As concentrations in Italian goat and bovine milk samples are attributable to the lack or scarce application of environmental disinfectants and pesticides in the areas where the farms are located (Licata et al., 2012).

\subsection{5. $\operatorname{Nickel~}(\mathrm{Ni})$}

The goat milk whey and cow milk whey samples contain similar Ni concentrations to each other, regardless of site, but are consistently lower than previously published values. Mean Ni concentrations (0.009 $\mathrm{mg} \mathrm{kg}^{-1}$ ) at the AZ location are more than 100 times lower than the only other published value $\left(1.22 \mathrm{mg} \mathrm{kg}^{-1}\right.$ ) of Turkish goat milk whey (Şanal et al., 2011). The mean values of $\mathrm{Ni}$ in cow milk whey $(0.01,0.008$, and $0.007 \mathrm{mg} \mathrm{kg}^{-1}$, from LB1, LB2, and LB3, respectively) are from 6 to 9 times lower than another result $\left(0.06 \mathrm{mg} \mathrm{kg}^{-1}\right)$ in the literature (Table 4) (Castro-González et al., 2018). 
Table 4

Trace element content in cow and goat milk whey samples reported in previous studies. Data are expressed in mg kg ${ }^{-1}$, as mean \pm standard deviation (SD).

\begin{tabular}{|c|c|c|c|c|c|c|c|}
\hline \multicolumn{3}{|c|}{ Goat milk whey } & \multicolumn{5}{|l|}{ Cow milk whey } \\
\hline $\begin{array}{l}\text { Trace } \\
\text { Element }\end{array}$ & $\begin{array}{l}\text { Herrera García et al., } \\
2006\end{array}$ & $\begin{array}{l}\text { Şanal et al., } \\
2011\end{array}$ & $\begin{array}{l}\text { Rivero Martino et al., } \\
2000\end{array}$ & $\begin{array}{l}\text { Rivero Martino et al., } \\
2001\end{array}$ & $\begin{array}{l}\text { Yüzbaşi et al. } \\
\text { (2009) }\end{array}$ & $\begin{array}{l}\text { Reykdal et al. } \\
\text { (2011) }\end{array}$ & $\begin{array}{l}\text { Castro-González et al. } \\
\text { (2018) }\end{array}$ \\
\hline $\begin{array}{l}\mathrm{V} \\
\mathrm{Mn}\end{array}$ & & $1.04 \pm 0.46$ & & & & & \\
\hline $\begin{array}{l}\mathrm{Fe} \\
\mathrm{Co}\end{array}$ & $0.30 \pm 0.10$ & & $0.062 \pm 0.003$ & $0.064 \pm 0.008$ & $2.5 \pm 0.2$ & $0.14 \pm 0.03$ & \\
\hline $\begin{array}{l}\mathrm{Cu} \\
\mathrm{Zn}\end{array}$ & $\begin{array}{l}\text { n.d. } \\
1.20 \pm 1.03\end{array}$ & & $0.0094 \pm 0.0009$ & $0.014 \pm 0.002$ & $\begin{array}{l}<0.02 \\
1.2 \pm 0.2\end{array}$ & $\begin{array}{l}0.016 \pm 0.003 \\
0.13 \pm 0.09\end{array}$ & $\begin{array}{l}0.05 \pm 0.03 \\
0.23 \pm 0.09\end{array}$ \\
\hline Se & $0.00486 \pm 0.00364$ & & $0.0041 \pm 0.0002$ & n.d. & & $0.0063 \pm 0.0006$ & \\
\hline $\mathrm{Al}$ & & $4.94 \pm 1.64$ & n.d. & n.d. & & & \\
\hline $\mathrm{Cr}$ & & & n.d. & n.d. & & & $0.02 \pm 0.01$ \\
\hline $\mathrm{Ni}$ & & $1.22 \pm 0.017$ & & & & & $0.06 \pm 0.02$ \\
\hline $\begin{array}{l}\mathrm{Sr} \\
\mathrm{U}\end{array}$ & & & $0.284 \pm 0.014$ & $0.270 \pm 0.010$ & & & \\
\hline As & & $1.96 \pm 0.25$ & & & & & $0.52 \pm 0.4$ \\
\hline $\mathrm{Cd}$ & & $0.05 \pm 0.01$ & $\begin{array}{l}\text { n.d. } \\
\text { n.d. }\end{array}$ & $\begin{array}{l}\text { n.d. } \\
\text { n.d. }\end{array}$ & $0.0037 \pm 0.0459$ & & \\
\hline $\begin{array}{l}\mathrm{Pb} \\
\mathrm{Ba} \\
\mathrm{Cs}\end{array}$ & & $\begin{array}{l}1.92 \pm 0.051 \\
\text { n.d. }\end{array}$ & $0.0009 \pm 0.0003$ & n.d & $0.1384 \pm 0.0459$ & & $0.07 \pm 0.02$ \\
\hline
\end{tabular}

n.d.: not detected.

\subsubsection{Uranium $(U)$}

Uranium is one of the most-studied toxic trace elements, yet we did not find any data in the literature on $U$ concentrations in cow or goat milk whey. In our samples, the mean $U$ concentrations were very low in both goat milk whey $\left(0.00010 \mathrm{mg} \mathrm{kg}^{-1}\right)$ and in cow milk whey samples (0.00009, 0.00006, and $0.00010 \mathrm{mg} \mathrm{kg}^{-1}$, from LB1, LB2, and LB3 respectively). At these concentrations, $U$ does not cause harmful effects on human health, as reported in a study of raw milk of water buffalos from Campania, Italy (Esposito et al., 2017).

\subsection{Rare earth elements (REEs)}

To the best of our knowledge, our work is the first study to determine REEs in milk whey. Therefore, no reference data are available in the literature with which to compare our results. The REE mean concentrations and standard deviations from this study are grouped by the two different milk whey types (Table 3). We subdivided the REEs into three groups: light-rare earth elements (LREEs) from La to $\mathrm{Nd}$, medium-rare earth elements (MREEs) from Sm to Ho, and heavy-rare earth elements (HREEs) from Er to Lu (Adeel et al., 2019). Medium rare earth elements (MREEs) are considered a subgroup that are not yet well defined (Tyler, 2004).

The mean concentrations of total REEs in goat milk whey samples (AZ) range from $0.23 \mathrm{ng} \mathrm{kg}^{-1}(\mathrm{Ho})$ to $12.7 \mathrm{ng} \mathrm{kg}^{-1}$ (Ce). The mean concentration of LREEs in goat milk whey samples range from $3.92 \mathrm{ng}$ $\mathrm{kg}^{-1}$ (Pr) to $12.7 \mathrm{ng} \mathrm{kg}^{-1}$ (Ce), while the MREE concentrations are between $0.23 \mathrm{ng} \mathrm{kg}^{-1}$ (Ho) and $4.89 \mathrm{ng} \mathrm{kg}^{-1}(\mathrm{Sm})$, and finally the level of HREEs are between $0.43 \mathrm{ng} \mathrm{kg}^{-1}$ (Er) and $2.36 \mathrm{ng} \mathrm{kg}^{-1}(\mathrm{Lu})$. Cerium was the most abundant element, followed by La, Sm, and $\mathrm{Nd}$.

The total REE concentrations in cow milk whey samples from all three LB sites are between $0.16 \mathrm{ng} \mathrm{kg}^{-1}$ (Ho) and $36.4 \mathrm{ng} \mathrm{kg}^{-1}$ (Tb). The mean concentrations of LREEs, MREEs, and HREEs at the LB3 location are consistently higher than the REE concentrations from the LB1 and LB2 samples, suggesting that either the REE composition of the soil, vegetation, or processing equipment may differ at the LB3 site compared to the other two LB locations.

\subsection{Principal component analysis (PCA)}

We applied a principal component analysis (PCA), using R software (https://www.r-project.org/accessed 21/12/2019), to multi-elemental concentrations of the 261 samples, in order to establish any possible relationship among the different types of milk whey across the Veneto region (Fig. 2). The first principal component (PC1) describes $34.8 \%$ of the samples, while the second principal component (PC2) encompasses $18.6 \%$ of the samples, for a total of $53.4 \%$ of the variance. The associated vectors of the PCA were calculated with trace and rare earth element concentrations and the location of the four groups of milk whey samples (AZ, LB1, LB2, and LB3). Most of the goat milk whey (AZ) samples are clustered around the positive abscissa and contain the elements $\mathrm{Fe}$, Se, As, and Cs. Cow milk whey samples from the LB1 and LB3 locations are mainly situated to the right of the ordinate, where only $\mathrm{U}$ and $\mathrm{Cd}$ strongly correlate with PC2. However, some samples from LB1 and LB3 are located in the bottom right quartile, close to the vectors of $\mathrm{Zn}, \mathrm{Ni}$, and Co, and inversely correlated with the REEs (the sum of the LEEs, MEEs, and HEEs). The LB2 samples are all located to the left of the ordinate, and are not represented by any of the vectors, with the possible exception of $\mathrm{Cu}$ (Fig. 2). Samples from the LB2 location generally have lower concentrations of TEs, except for $\mathrm{Ni}$, than samples from the other groups (Table 3), which may account for this distribution within the PCA. In addition, previous studies in the Veneto region assessed the pollution level of TEs and organic contaminants in samples (e.g. soil, wine and grapes) and other environmental indicators such as lichens and moss. Human activities throughout the region cause widespread contaminants that vary in space and time. The lower levels of TEs for the LB2 samples were likely influenced by a less impacted area than LB1 and LB3 as these latter sites are subject to intensive agricultural practices, air pollutants, and a different pedo-geochemical baseline content of TEs in soil (Cesa, Bizzotto, Ferraro, Fumagalli, \& Nimis, 2006; Giandon, Dalla Rosa, Garlato, \& Ragazzi, 2012; Nimis, Lazzarin, Lazzarin, \& Skert, 2000) as well as variations in the local production processes (Pepi \& Vaccaro, 2018).

\section{Conclusions}

This is the first study of the presence and distribution of both TEs and REEs in cow and goat milk whey samples after the production of traditional dairy products from the Veneto region, in northeastern Italy. Iron has the highest concentration of any TE in both cow and goat milk whey samples followed by $\mathrm{Cu}, \mathrm{Zn}$, Se, and $\mathrm{Sr}$. These substantial values of $\mathrm{Fe}$ and $\mathrm{Cu}$ may result from the leaching of metals from materials such as utensils and containers in which the dairy products are processed. In contrast, the Se and $\mathrm{Zn}$ concentrations may depend upon their content in the animal feed and/or the physiological difference between cows and goats. Finally, the $\mathrm{Sr}$ concentrations in milk whey can be influenced by the lactation state of the animal and the ability of plants to absorb this 
element.

TE and REE concentrations can vary even within the milk from the same animal species (cow) and from the same general region (Veneto, Italy). Our results show that the majority of the elements from the LB2 location had lower values than those from LB1 and LB3. As these locations all process cow milk, these variations may be attributable to different types of equipment and containers used during the production of dairy products and/or differences in cattle feed.

Samples of cow and goat milk whey derived from all locations for this work presented lower levels of toxic metals $(\mathrm{Pb}, \mathrm{Cd}, \mathrm{As}$, and $\mathrm{Ni}$ ) with the exception of $\mathrm{Cr}$ concentrations, where both cow and goat milk whey samples contain similar levels of this element. Most toxic element concentrations (Cd, Ni, Cr, and $\mathrm{U}$ ) are comparable in both types of milk whey. However, our results indicate that $\mathrm{Pb}$ and As have higher concentrations in goat milk whey than in cow milk whey. In general, the low concentrations of toxic elements in the two types of milk whey should not pose any risk to human health, as defined by European regulations.

Throughout the total data set, the concentrations of REEs are lower in goat milk whey (AZ) than in any of the cow milk whey (LB) samples. The REE concentrations vary by location, where samples from LB3 have higher concentrations compared to the LB1 and LB2 samples. A PCA demonstrates that the TEs and REEs substantially vary by location, demonstrating that the geographical area and/or milk production methods are the most important aspects in the chemical composition of the TEs and REEs in cow and goat milk whey. Future studies of TEs and REEs in the soil and plants on which the cows and goats graze can help determine the role of diet in the TEs and REEs present in the milk whey. Determining the root cause of the TEs and REEs in milk whey is advisable due to the accumulation of TEs and REEs in the food chain which can pose a risk to human health.

\section{CRediT authorship contribution statement}

Raffaello Tedesco: Investigation, Methodology, Formal analysis, Data curation, Writing - original draft, Writing - review \& editing. Maria del Carmen Villoslada Hidalgo: Data curation, Validation, Writing original draft, Writing - review \& editing. Massimiliano Vardè: Visualization, Data curation, Supervision, Writing - original draft, Writing review \& editing. Natalie M. Kehrwald: Visualization, Writing - review \& editing. Carlo Barbante: Resources, Writing - review \& editing. Giulio Cozzi: Conceptualization, Funding acquisition, Project administration, Supervision, Formal analysis, Writing - review \& editing.

\section{Acknowledgements}

The present work was promoted by the National Research Council of Italy (Consiglio Nazionale delle Ricerche, CNR) and was financially supported by the "Fondo Sociale Europeo del Veneto", "Il siero di latte da rifiuto a risorsa: valorizzazione e riutilizzo attraverso uno studio di caratterizzazione chimica" (project n.: 436-3-2121-2015). The authors gratefully acknowledge the help of Dr. Elisa Stella (CNR-ISP) for her contribution to the graphical part and Dr. Fabiana Corami (CNR-ISP) for helpful suggestions during chemical analysis. We also thank Shannon Mahan (USGS) and Janet Slate (USGS) for their suggestions to improve the manuscript. We would like to thank "LatteBusche SCA" and "Società Agricola AI ZEI snc" for providing the milk whey samples. Any use of trade, firm, or product names is for descriptive purposes only and does not imply endorsement by the U.S. Government.

\section{References}

Aceto, M., Bonello, F., Musso, D., Tsolakis, C., Cassino, C., \& Osella, D. (2018). Wine Traceability with rare earth elements. Beverages, 4(23), 1-11. https://doi.org/ 10.3390/beverages4010023.

Adeel, M., Lee, J. Y., Zain, M., Rizwan, M., Nawab, A., Ahmad, M. A., et al. (2019). Cryptic footprints of rare earth elements on natural resources and living organisms.
Environment International, 127(January), 785-800. https://doi.org/10.1016/j. envint.2019.03.022.

Ayar, A., Sert, D., \& Akin, N. (2009). The trace metal levels in milk and dairy products consumed in middle Anatolia - Turkey. Environmental Monitoring and Assessment, 152 (1-4), 1-12. https://doi.org/10.1007/s10661-008-0291-9.

Bandoniene, D., Meisel, T., Rachetti, A., \& Walkner, C. (2018). A tool to assure the geographical origin of local food products (glasshouse tomatoes) using labeling with rare earth elements. Journal of the Science of Food and Agriculture, 98(12), 4769-4777. https://doi.org/10.1002/jsfa.9124.

Bini, C., Fontana, S., \& Spiandorello, M. (2013). Towards food safety. Potentially harmful elements (PHEs) fluxes from doil to food crops. Environmental Quality, 10, 23-36. https://doi.org/10.6092/issn.2281-4485/3930.

Brandelli, A., Daroit, D. J., \& Folmer Corrêa, A. P. (2015). Whey as a source of peptides with remarkable biological activities. Food Research International, 73, 149-161. https://doi.org/10.1016/j.foodres.2015.01.016.

Castro-González, N. P., Calderón-Sánchez, F., Castro de Jesús, J., Moreno-Rojas, R., Tamariz-Flores, J. V., Pérez-Sato, M., et al. (2018). Heavy metals in cow's milk and cheese produced in areas irrigated with waste water in Puebla, Mexico. Food Additives and Contaminants: Part B, 11(1), 33-36. https://doi.org/10.1080/ 19393210.2017.1397060.

Cesa, M., Bizzotto, A., Ferraro, C., Fumagalli, F., \& Nimis, P. L. (2006). Assessment of intermittent trace element pollution by moss bags. Environmental Pollution, 144(3), 886-892. https://doi.org/10.1016/j.envpol.2006.02.004.

Coni, E., Bocca, A., Coppolelli, P., Caroli, S., Cavallucci, C., \& Marinucci, M. T. (1996). Minor and trace element content in sheep and goat milk and dairy products. Food Chemistry, 57(2), 253-260. https://doi.org/10.1016/0308-8146(95)00216-2.

Coni, E., Bocca, A., Ianni, D., \& Caroli, S. (1995). Preliminary evaluation of the factors influencing the trace element content of milk and dairy products. Food Chemistry, 52 (2), 123-130. https://doi.org/10.1016/0308-8146(94)P4190-Q.

Danezis, G. P., Tsagkaris, A. S., Brusic, V., \& Georgiou, C. A. (2016). Food authentication: State of the art and prospects. Current Opinion in Food Science, 10, 22-31. https://doi. org/10.1016/j.cofs.2016.07.003.

E.C. Regulation. (2006). Commission Regulation (EC) No 1881/2006 of 19 December 2006, setting maximum levels for certain contaminants in foodstuffs. Official Journal of the European Union, L364/5-L364/22.

Esposito, M., Miedico, O., Cavallo, S., Pellicanò, R., Rosato, G., Baldi, L., et al. (2017). Trace elements in raw milk of buffaloes (Bubalus bubalis) from Campania, Italy. Food Chemistry, 233, 378-384. https://doi.org/10.1016/j.foodchem.2017.04.124.

FAO, WHO \& JEFCA, FAO JECFA. (2011). Safety evaluation of certain contaminants in food. In WHO food additives series: 63. FAO JECFA Monographs 8, 778.

Giandon, P., Dalla Rosa, A., Garlato, A., \& Ragazzi, F. (2012). Evaluation of soil diffuse contamination in Venice region (Italy). EQA - Environmental Quality/Qualité de l'Environnement/Qualità Ambientale, 9, 11-18. https://doi.org/10.6092/issn.22814485/3733.

Giusti, L., \& Taylor, A. (2007). Natural and anthropogenic contamination of the FrattaGorzone river (Veneto, Italy). Environmental Monitoring and Assessment, 134(1-3), 211-231. https://doi.org/10.1007/s10661-007-9611-8.

González-Montaña, J. R. (2009). Metales pesados en carne y leche y certifi cación para la Unión Europea. UE), 305-310.

Herrera García, M. I., Peláez Puerto, P., Fresno Baquero, M., Rodríguez Rodríguez, E., Darías Martín, J., \& Díaz Romero, C. (2006). Mineral and trace element concentrations of dairy products from goats' milk produced in Tenerife (Canary Islands). International Dairy Journal, 16(2), 182-185. https://doi.org/10.1016/j. idairyj.2005.01.011.

Hoac, T., Lundh, T., Purup, S., Önning, G., Sejrsen, K., \& Åkesson, B. (2007). Separation of selenium, zinc, and copper compounds in bovine whey using size exclusion chromatography linked to inductively coupled plasma mass spectrometry. Journal of Agricultural and Food Chemistry, 55(10), 4237-4243. https://doi.org/10.1021/ jf070169x.

Innocente, N., \& Biasutti, M. (2013). Automatic milking systems in the protected designation of origin montasio cheese production chain: Effects on milk and cheese quality. Journal of Dairy Science, 96, 740-751. https://doi.org/10.3168/jds.20125512 .

Joebstl, D., Bandoniene, D., Meisel, T., \& Chatzistathis, S. (2010). Identification of the geographical origin of pumpkin seed oil by the use of rare earth elements and discriminant analysis. Food Chemistry, 123(4), 1303-1309. https://doi.org/10.1016/ j.foodchem.2010.06.009.

Lante, A., Lomolino, G., Cagnin, M., \& Spettoli, P. (2006). Content and characterisation of minerals in milk and in Crescenza and Squacquerone Italian fresh cheeses by ICPOES. Food Control, 17(3), 229-233. https://doi.org/10.1016/j. foodcont.2004.10.010.

Levkov, V., Stafilov, T., Pacinovski, N., Bačeva, K., Mateva, N., \& Gjorgovska, N. (2017). Content of major and trace elements in raw ewes' milk used for production of traditional white brined cheese. Slovak Journal of Animal Science, 2017(1), 7-14.

Licata, P., Di Bella, G., Potortì, A. G., Lo Turco, V., Salvo, A., \& Dugo, G. mo (2012). Determination of trace elements in goat and ovine milk from Calabria (Italy) by ICPAES. Food Additives \& Contaminants Part B Surveillance, 5(4), 268-271. https://doi. org/10.1080/19393210.2012.705335.

Licata, P., Trombetta, D., Cristani, M., Giofrè, F., Martino, D., Calò, M., et al. (2004). Levels of "toxic" and "essential" metals in samples of bovine milk from various dairy farms in Calabria. Italy. Environment International, 30(1), 1-6. https://doi.org/ 10.1016/S0160-4120(03)00139-9.

Li, X., Chen, Z., Chen, Z., \& Zhang, Y. (2013). A human health risk assessment of rare earth elements in soil and vegetables from a mining area in Fujian Province, Southeast China. Chemosphere, 93(6), 1240-1246. https://doi.org/10.1016/j. chemosphere.2013.06.085. 
Malbe, M., Otstavel, T., Kodis, I., \& Viitak, A. (2010). Content of selected micro and macro elements in dairy cows' milk in Estonia. Agronomy Research, 8(Ii), 323-326.

Miedico, O., Tarallo, M., Pompa, C., \& Chiaravalle, A. E. (2016). Trace elements in sheep and goat milk samples from Apulia and Basilicata regions (Italy): Valuation by multivariate data analysis. Small Ruminant Research, 135, 60-65. https://doi.org/ 10.1016/j.smallrumres.2015.12.019.

Muhib, M. I., Chowdhury, M. A. Z., Easha, N. J., Rahman, M. M., Shammi, M., Fardous, Z., et al. (2016). Investigation of heavy metal contents in cow milk samples from area of Dhaka, Bangladesh. International Journal of Flow Control, 3(1), 1-10. https://doi.org/10.1186/s40550-016-0039-1.

Nimis, P. L., Lazzarin, G., Lazzarin, A., \& Skert, N. (2000). Biomonitoring of trace elements with lichens in Veneto (NE Italy). The Science of the Total Environment, 255 (1-3), 97-111. https://doi.org/10.1016/S0048-9697(00)00454-X.

Özturan, K., \& Atasever, M. (2018). Mineral elements and heavy metals in milk and dairy products [Süt ve Ürünlerinde Mineral Maddeler ve Ağır Metaller]. Atatürk Üniversitesi Veteriner Bilimleri Dergisi, 13(2), 229-241. https://doi.org/10.17094/ ataunivbd.317822.

Pagano, G., Guida, M., Tommasi, F., \& Oral, R. (2015). Health effects and toxicity mechanisms of rare earth elements-knowledge gaps and research prospects. Ecotoxicology and Environmental Safety, 115, 40-48. https://doi.org/10.1016/j. ecoenv.2015.01.030.

Pepi, S., \& Vaccaro, C. (2018). Geochemical fingerprints of "Prosecco" wine based on major and trace elements. Environmental Geochemistry and Health, 40(2), 833-847. https://doi.org/10.1007/s10653-017-0029-0.

Petrović, S. M., Savić, S. R., \& Petronijević, Ž. B. (2016). Macro- and micro-element analysis in milk samples by inductively coupled plasma - optical emission spectrometry. Acta Periodica Technologica, 47, 51-62. https://doi.org/10.2298/ APT1647051P.

Poto, L., Gabrieli, J., Crowhurst, S. J., Appleby, P. G., Ferretti, P., Surian, N., ... Barbante, C. (2013). The first continuous Late Glacial - Holocene peat bog multiproxy record from the Dolomites (NE Italian Alps). Quaternary International, 306, 71-79. https://doi.org/10.1016/j.quaint.2013.05.001.

Prashanth, L., Kattapagari, K. K., Chitturi, R. T., Baddam, V. R. R., \& Prasad, L. K. (2015) A review on role of essential trace elements in health and disease. Journal of Dr. NTR
University of Health Sciences, 4(2), 75-85. https://doi.org/10.4103/22778632.158577.

Reykdal, O., Rabieh, S., Steingrimsdottir, L., \& Gunnlaugsdottir, H. (2011). Minerals and trace elements in Icelandic dairy products and meat. Journal of Food Composition and Analysis, 24(7), 980-986. https://doi.org/10.1016/j.jfca.2011.03.002.

Rivero Martino, F. A., Fernández Sánchez, M. L., \& Sanz Medel, A. (2000). Total determination of essential and toxic elements in milk whey by double focusing ICPMS. J. Anal. At. Spectrom., 15(2), 163-168. https://doi.org/10.1039/A907925D.

Rivero Martino, F. A., Fernández Sánchez, M. L., \& Sanz-Medel, A. (2001). The potential of double focusing-ICP-MS for studying elemental distribution patterns in whole milk, skimmed milk and milk whey of different milks. Analytica Chimica Acta, 442 (2), 191-200. https://doi.org/10.1016/S0003-2670(01)01170-9.

Rodríguez-Bermúdez, R., López-Alonso, M., Miranda, M., Fouz, R., Orjales, I., \& HerreroLatorre, C. (2018). Chemometric authentication of the organic status of milk on the basis of trace element content. Food Chemistry, 240(May 2017), 686-693. https:// doi.org/10.1016/j.foodchem.2017.08.011.

Şanal, H., Güler, Z., \& Park, Y. W. (2011). Profiles of non-essential trace elements in Ewe and goat milk and their yoghurt, torba yoghurt and whey. Food Additives \& Contaminants Part B Surveillance, 4(4), 275-281. https://doi.org/10.1080/ 19393210.2011.617520.

Spalla, S., Baffi, C., Barbante, C., Turretta, C., Cozzi, G., Beone, G. M., et al. (2009). Determination of rare earth elements in tomato plants by inductively coupled plasma mass spectrometry techniques. Rapid Communications in Mass Spectrometry, 23(20), 3285-3292. https://doi.org/10.1002/rcm.4244.

Tyler, G. (2004). Rare earth elements in soil and plant systems-a review. Plant and Soil, 267(1-2), 191-206. https://doi.org/10.1007/s11104-005-4888-2.

World Health Organization. (1996). Trace elements in human nutrition and health World Health Organization. World Health Organization, 1-360. Retrieved from https://apps. who.int/iris/bitstream/handle/10665/37931/9241561734_eng.pdf.

Yüzbași, N., Sezgin, E., Yildirim, Z., \& Yildirim, M. (2009). Changes in Pb, Cd, Fe, Cu and Zn levels during the production of kaşar cheese. Journal of Food Quality, 32(1), 73-83. https://doi.org/10.1111/j.1745-4557.2007.00167.x. 